\title{
Perspective plan for sustainable eel management in Lake Poso, Central Sulawesi
}

\author{
Triyanto ${ }^{1, *}$, Gadis S. Haryani1, Lukman ${ }^{1}$, Hendro Wibowo $^{1}$, Fauzan Ali ${ }^{1}$, Hidayat ${ }^{1}$, \\ Fachmijany Sulawesty ${ }^{1}$, Foni A. Setiawan ${ }^{1}$, Endra Triwisesa ${ }^{1}$, Angga Dwinovantyo ${ }^{2}$, \\ Mohammad Riyanto ${ }^{3}$, Octavianto Samir ${ }^{1}$, and Eva Nafisyah ${ }^{1}$ \\ ${ }^{1}$ Research Center for Limnology, National Research and Innovation Agency (BRIN), Cibinong, \\ Indonesia \\ ${ }^{2}$ Research Center for Deepsea, National Research and Innovation Agency (BRIN), Ambon, Indonesia \\ ${ }^{3}$ Faculty of Fisheries and Marine Sciences IPB University, Indonesia
}

\begin{abstract}
Lake Poso has high eel potential and a strategic position in supporting the development of eel fisheries in Sulawesi. Lake Poso is out of 15 national priority lakes in natural resources and environmental management programs. The catch of eel from Lake Poso is reported to have been decreasing for the last twenty years. Several factors causing the decline in eel populations are fishing activities, disruption in migration routes, and other factors such as changes in habitat and environmental conditions. The sustainability of the life of the Poso eel is determined by the success of the eel migration process. The migration of adult eels to the sea and young eels from glass eels to freshwater habitats must continue. The perspective plans that can be done to manage Poso's eel resources include 1) Socializing the eco-biological characteristics of eels as catadromous fish; 2) Establishing conservation areas and regulation of eel fishing; 3) Increasing eel population through restocking 4) Integrating fisheries and aquaculture activities; 5) Developing eel culture technology through size segmentation production; 6) Developing an eel migration monitoring system; 7) Building a cross-sectoral forum and put a joint action program; 8) Proposing the Poso eel Research and Conservation Center.
\end{abstract}

\section{Introduction}

Lake Poso is located in Poso Regency, Central Sulawesi. The area of Lake Poso is $323.2 \mathrm{~km}^{2}$, while the area of Poso's catchment area is $1271 \mathrm{~km}^{2}$ [1]. There are approximately 13 rivers as Lake Poso inlets. The outlet of Lake Poso is the Poso River, which flows to Tomini Bay, and the length of about $52 \mathrm{~km}[1,2]$. Poso's inland waters are used as energy producers through hydroelectric power, fisheries, tourist areas, and irrigation. Lake Poso is one of 15 national priority lakes. One of the reasons is degradation in the Poso watershed area, sedimentation, and decreased water quality [3].

Lake Poso and its rivers are well known as eel habitats. There are five species of eels, namely Anguilla marmorata, Anguilla celebesensis, Anguilla bicolor pacifica, Anguilla

\footnotetext{
*Corresponding author: triyanto@limnologi.lipi.go.id
} 
interiors, and Anguilla borneensis [4]. Eels are catadromous fish that migrate to marine waters to spawn $[5,6]$. Eel larvae will return to freshwater through river estuaries. The Poso River estuary is one of the important estuaries in Tomini Bay because it is the location for eel larvae migration. The eel in Lake Poso is an export commodity. Based on the research reviewed [7], eel production in 1970 was estimated at 22 tons, in 1990 it reached 41.5 tons, in 1998 it was 30.5 tons, and in 2009 the production was only 6.49 tons (Fisheries Agency of Poso Regency; unpublished). According to research [7], the potential for glass eel from the Poso estuary reaches 50,000,000 ind./year. The glass eel is traded to other areas outside Poso, such as Makassar, Surabaya, Bali, and Jakarta [8].

Research on eel management began to be carried out due to the decreasing eel population, which affected the production of eel fisheries. Since 1980 the eel population in Europe has decreased dramatically [9] and in other countries where eels are also found, such as Japan, China, and Korea $[10,11]$. At the same time, in Indonesia eel population hence eel fishery has also begun to decline, including in the Poso eel fishery. In Indonesia, the decline in eel population and eel fishery production has also begun to decline, as is the Poso, Central Sulawesi [7, 12].

Management efforts are needed, including biota management (eel), habitat management, and the socio-economic management of fishers to continue the utilization of eel resources. The built management model requires a comprehensive understanding of eels' biological and ecological aspects, including habitat conditions and migration processes between marine, estuaries, and freshwater ecosystems. Socio-economic conditions and the institutional role of eel-catching business actors must also be considered. These factors significantly affect the use of resources. They are essential to support the management of eel fisheries so that existing eel resources can still be used sustainably. This paper contains thoughts on managing eel resources in Poso waters by reviewing the research results carried out and are currently being conducted. The purpose of the preparation of this paper is to provide input and suggestions for sustainable eel management.

\section{Environmental characteristics of Lake Poso}

Lake Poso is located in Poso Regency, Central Sulawesi Province, at a geographical position of $1^{\circ} 44^{\prime}-2^{\circ} 04^{\prime} \mathrm{S}$ and $120^{\circ} 32^{\prime}-120^{\circ} 43^{\prime} \mathrm{E}$, at an altitude of $\pm 600 \mathrm{~m}$ above sea level [3]. The area around Lake Poso is generally hilly and mountainous, with elevations ranging from 400 to $1200 \mathrm{~m}$ with a slope of $15-40 \%$. Plain areas with slopes of less than $2 \%$ are found on the shores of the lake on the southeast, south, west, and north sides [3]. Lake Poso is the beginning of the Poso River. Characteristic of the river with rapids and strong currents flowing into Tomini Bay.

The water quality of the Poso watershed in the March and June 2021 is characterized by the $\mathrm{pH}$ of the waters that tends to be alkaline, especially in lake waters. The water temperature is between $27.30-29.24^{\circ} \mathrm{C}$, the dissolved oxygen level is relatively high $(>7.0 \mathrm{mg} / \mathrm{L})$. The transparency of the waters in Lake Poso was $8.82-11.29 \mathrm{~m}$, while the water transparency in the river and estuary was lower, ranging from $0.60-0.87 \mathrm{~m}$. The total suspended solids (TSS.), total nitrogen, and phosphorus content in the lake area show a lower value and increase towards the estuary (Table 1). Based on national water quality standards [13], the results of water quality measurements such as transparency, total nitrogen (TN), total phosphor (TP.), and Chlorophyll-a indicate that Lake Poso is still in an oligotrophic lake. Meanwhile, the Poso River and Poso Estuary are mesotrophic [13]. 
Table 1. Water quality in Poso watershed in March and June 2021.

\begin{tabular}{lcccc}
\hline Parameter & \multicolumn{4}{c}{ Location } \\
\cline { 2 - 5 } & Lake & Out Let & River & Estuary \\
\hline pH & $9.16-9.66$ & $9.03-9.40$ & $7.97-9.43$ & $8.81-9.72$ \\
DO $(\mathrm{mg} / \mathrm{L})$ & $7.29-7.50$ & $7.34-7.47$ & $7.13-8.0$ & $7.83-7.93$ \\
Temperature $\left({ }^{\circ} \mathrm{C}\right)$ & $28.20-29.24$ & $27.30-28.46$ & $27.50-27.90$ & $28.44-28.79$ \\
Salinity $(\mathrm{ppt})$ & 0 & 0 & 0 & $0.7-0.8$ \\
Transparency $(\mathrm{m})$ & $8.82-11.29$ & $2-3$ & 0.87 & $0.60-0.80$ \\
TSS $(\mathrm{mg} / \mathrm{L})$ & $1.2-1.6$ & $0.9-1.3$ & $2.4-4.5$ & $45.8-53.4$ \\
TN $(\mathrm{mg} / \mathrm{L})$ & $0.044-0.233$ & $0.029-0.438$ & $0.031-0.032$ & $0.062-0.318$ \\
TP $(\mathrm{mg} / \mathrm{L})$ & $0.011-0.012$ & $0.034-0.048$ & $0.079-0.085$ & $0.039-0.064$ \\
Chlorophyll-a $\left(\mathrm{mg} / \mathrm{m}^{3}\right)$ & $0.189-0.485$ & $0.476-0.762$ & $0.288-0.498$ & $0.332-0.463$ \\
\hline
\end{tabular}

The Poso River has a length of $\pm 68.70 \mathrm{~km}$ with a drainage area of $1101.87 \mathrm{~km}^{2}$ [14]. A hydroelectric power plant (PLTA) utilizes the swift flow of the Poso River water in the Sulewana area. There is a dam located at $1^{\circ} 40.165^{\prime} \mathrm{S} ; 120^{\circ} 39,140^{\prime} \mathrm{E}$ (DAM Poso 1: 120 MW) and at $1^{\circ} 38,897^{\prime} \mathrm{S} ; 120^{\circ} 39,490^{\prime} \mathrm{E}$ (DAM Poso 2: $195 \mathrm{MW}$ ). In both dams, fishway installations have been built to provide migration routes for eels. Poso 2 fishway has been operating since 2012, and Poso 1 fishway has been operating since August 2019 [15]. The effectiveness of this fishway is still being studied whether the function of the fishway is as expected. The results of initial observations revealed that there was young eel with sizes between $10-20 \mathrm{~cm}$ in the fishway of the two dams (Fig. 1.). Monitoring eel migration on the fishway is essential to identify and ensure the eel cycle continues

The Poso River flows into Tomini Bay, in Poso City. Tomini Bay is the largest bay in Sulawesi and Indonesia, with a maximum of $2000 \mathrm{~m}$ [16]. The width of the Poso River estuary is about $120 \mathrm{~m}$, with a depth of between 1.5-3 m. The water transparency at the Poso River estuary in March and June 2021 was between $0.60-0.80 \mathrm{~m}$. The total suspended solids content reaches $45.8-53.5 \mathrm{mg} / \mathrm{L}$. The surface water salinity at the Poso River estuary was 0.7 $0.8 \mathrm{ppt}$. The results of water quality measurement at the Poso River estuary can be seen in Table 1. The trophic level of the Poso River estuary is based on the criteria of Regulation of Ministry of Environment and Forestry No. 28.2009 [13] belongs to mesotrophic waters.

\section{Eel fisheries condition of Lake Poso}

The Poso watershed is an eel habitat area. There are five eel species, with the dominant types of eel caught being $A$. marmorata and $A$. Celebesensis [4]. Eel has economic value and is a fishing target by the community. The capture of eel was carried out at the adult stage and juveniles during the glass eel stage. Adult eels are caught using several fishing gears such as fishing rods, traps, and trap fences. Locally, the trap fence is known as "waya masapi". This fishing gear is placed transversely at the Lake Poso outlet in the Tentena. Most of the adult eels are caught by waya masapi fish trap. 


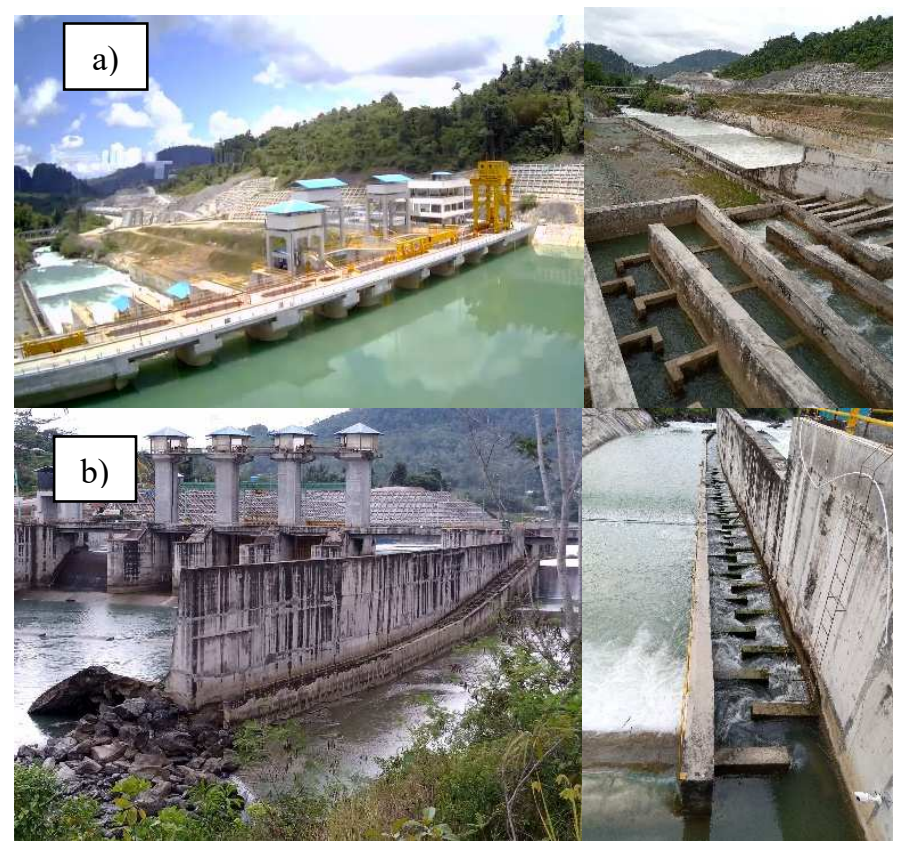

Fig. 1. Dam Poso 1 (a), dam Poso 2 (b), and fishway installation on each dam.

(Photo by Triyanto, June 2021)

The catch of adult eels has been reported to have decreased over the past 30 years. In 1990 the eel catch was recorded at 41.5 tons and decreased in 1998 to 30.5 tons in 1998. In 2009 the production of eel catches was only 6.49 tons [7]. The data collection results from the Fisheries Service of Poso Regency (unpublished data) show that the eel catch in 20172019 was in the range of 6.7-15.5 tons. In recent data collected, the number of eels caught in April-June 2021 in the Tentena area was only 656 eels with a total weight of 3,202 kg. The size of the eel caught was dominated by the size of 98-129 cm, with a weight between 5-9 kg/Ind. (Fig. 2.).

Compared to the research results in 2012 [12], the size of the caught eels did not show any significant changes. In 2012, the eel caught in Tentena was $60-130 \mathrm{~cm}$, with individual weight varying from 330 to $5000 \mathrm{~g}$. The size of an eel when migrating downstream is between 4.1 to $7.2 \mathrm{~kg} / \mathrm{Ind}$. [4]. Recently the number of eels being caught has been decreasing [7, 12]. The decline in eel population in the Poso watershed is caused by the intensity of eel fishing at the Poso Lake outlet, glass eel fishing at the Poso River estuary, and disturbances in the eel migration path hydroelectric power.

The glass eel at the Poso River estuary is also a target for fishing by the local community. The catch of glass eel is used as an eel seed for aquaculture. The price of glass eel ranges from Rp. 200.000-Rp.300.000/kg [17, 18]. The capture of glass eels is carried out at night during the new moon period. The fishing gear was originally used as a hand net, namely "seser". It is shaped triangular with a length of $100 \mathrm{~cm}$ with a mouth opening of $75 \mathrm{~cm}$ [19]. In the last five years, the glass eel fishing gear has become a trap net called "gorong gorong" (fyke net). This fishing gear consists of the front consisting of the wings and the mouth of the net, the middle, and the back of the catch collecting bag (Fig. 3.). Wing length between 2-4 m, height $0.5-1 \mathrm{~m}$, net mouth opening height $0.75-1.5 \mathrm{~m}$, width $0.5-1.0$, body length 8 $12 \mathrm{~m}$ and pouch length $1.5 \mathrm{~m}$ [18]. 

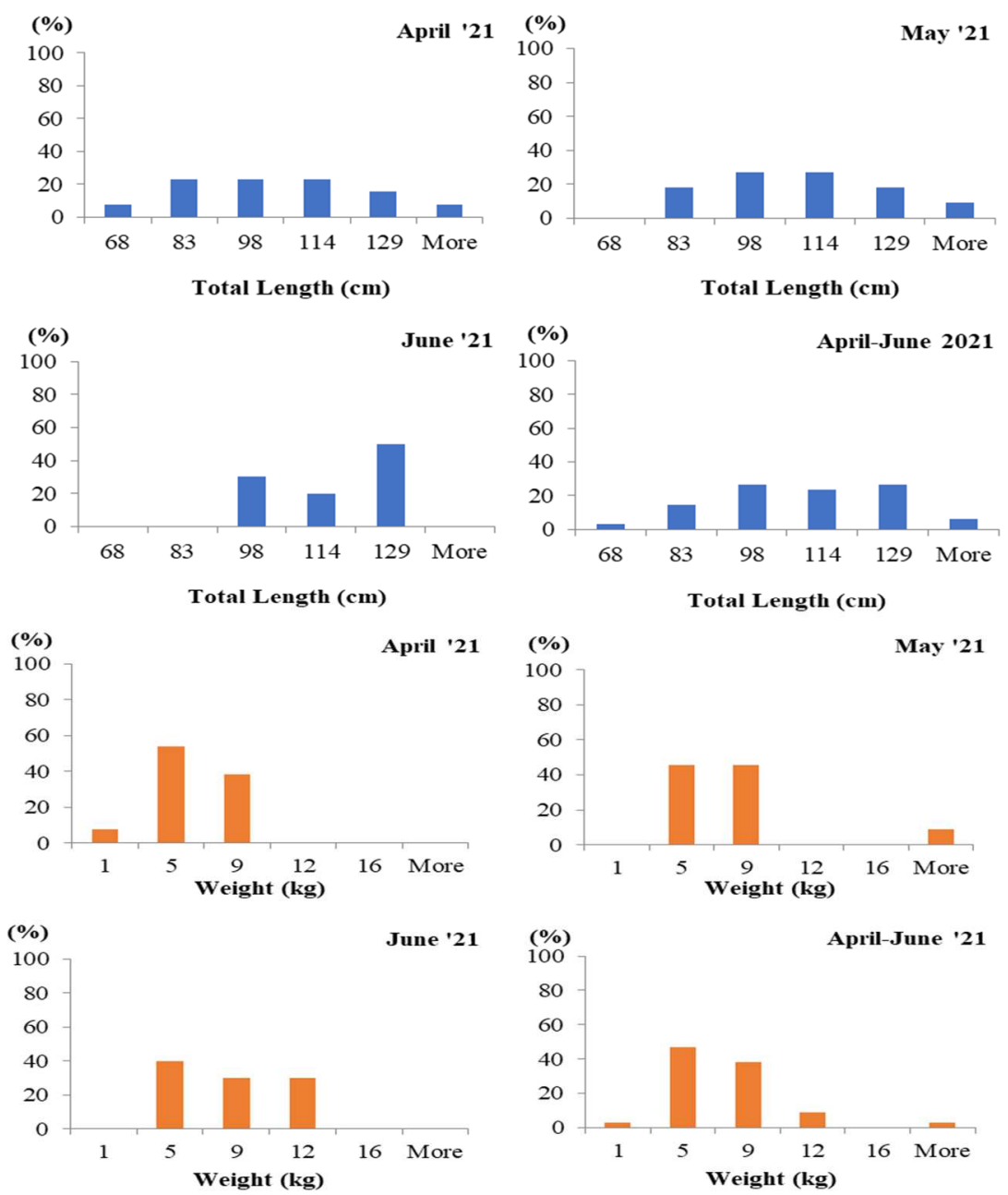

Fig. 2. Size distribution of eels caught in the Lake Poso, April-June 2021.

Based on research [20], the migration of glass eels to the waters of the Poso River estuary takes place throughout the year. The peak of glass eel migration takes place in August. There are six species of glass eel, such as A. celebesensis, A. marmorata, A. interioris, A. bicolor pacifica, and two other species that have not been identified. A. celebesensis and $A$. marmorata are the dominant species. The catch of glass eel in 2010-2011 is estimated at $15,000,000$ Ind./year or equivalent to 2.5 tons/year [7]. The results of observations of the abundance of glass eels in April-June 2021 was 3,512-13,257 ind./night or 666-2.254 g/night. According to Mr. Irwan D.J. Lamoa (glass eel fisher), the glass eel catch during the migration season could reach $20-60 \mathrm{~kg} / \mathrm{month}$. However, the glass eel catch from this Poso estuary has not been well recorded. Hence it could be a constraint in further evaluation and management of these resources. 


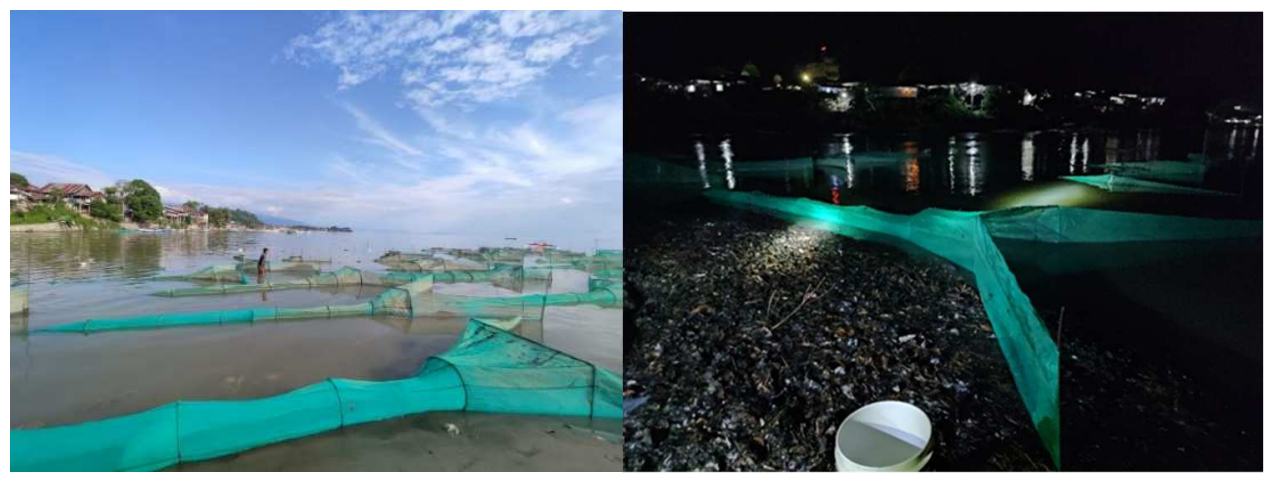

Fig. 3. Glass eel fishing gear at the Poso River estuary (fyke net).

(Photo by: Kurniawan, June 2021)

\section{Perspective plan for sustainable eel management}

The management of eel resources has been carried out since the early 20th century through several studies. Eel research at that time focused on research on the mysteries of the eel life cycle [21]. Other studies continue to develop research to cultivate eels through artificial spawning [22], habitat restoration, restocking, and eel fishing policies [9].

Management of eel resources in Poso waters is necessary to be done. The decline in catch production, unregulated fishing rates, obstacles in the eel migration path, and the other environmental pressures are essential points to be considered. Research Center for Limnology -LIPI through LPDP Rispro Invitasi Research Program conduct to implement the previous research and the ongoing research to maintain the sustainability of eel production in Poso Waters in 2020-2021. Perspective plans are presented in this paper to provide input to the local government of Poso Regency and business actors who are directly or indirectly involved (Fig. 4.). The recommended perspective plan in eel management is as follows:

\subsection{Socialization of the eco-biological nature of eels as catadromous fish}

The level of community knowledge about eel resources in Poso is still deficient. The level of knowledge of fishers and the community on the eel and the need for eel conservation was only $20 \%$ [12]. As catadromous fish, eels are not well understood by the community and fishers, especially on eel's life cycle, which must migrate to the sea to reproduce. The topics for socialization are the understanding of the eel's three life cycle phases, the ocean phase, the estuary phase, and the freshwater phase [10,23] (Fig. 5). 


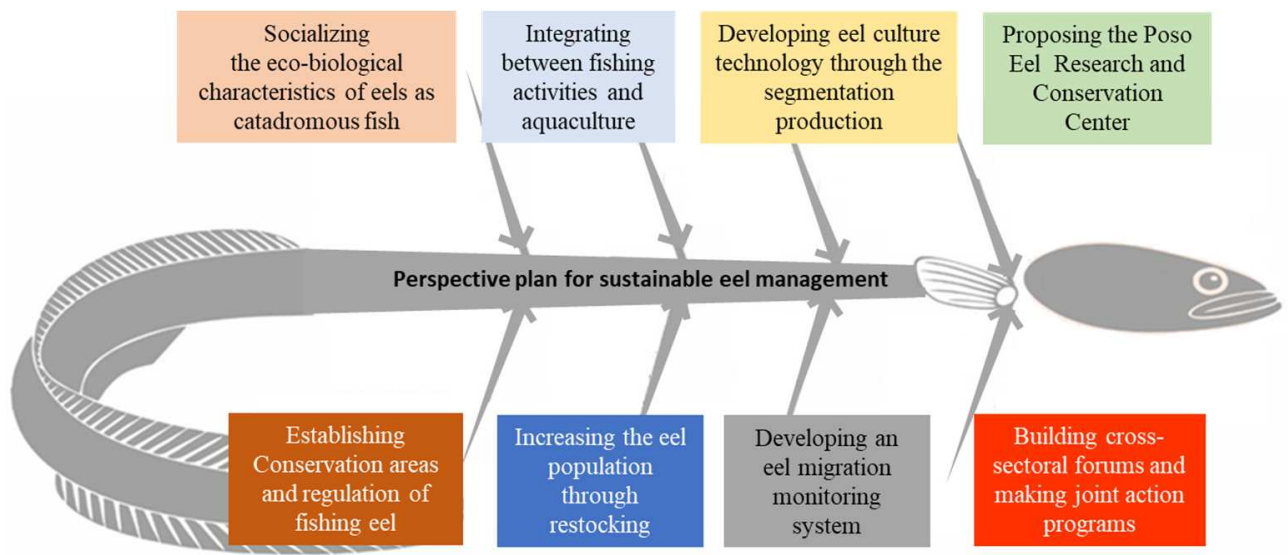

Fig. 4. Sustainable management perspective plans scheme for Poso eel fishery.

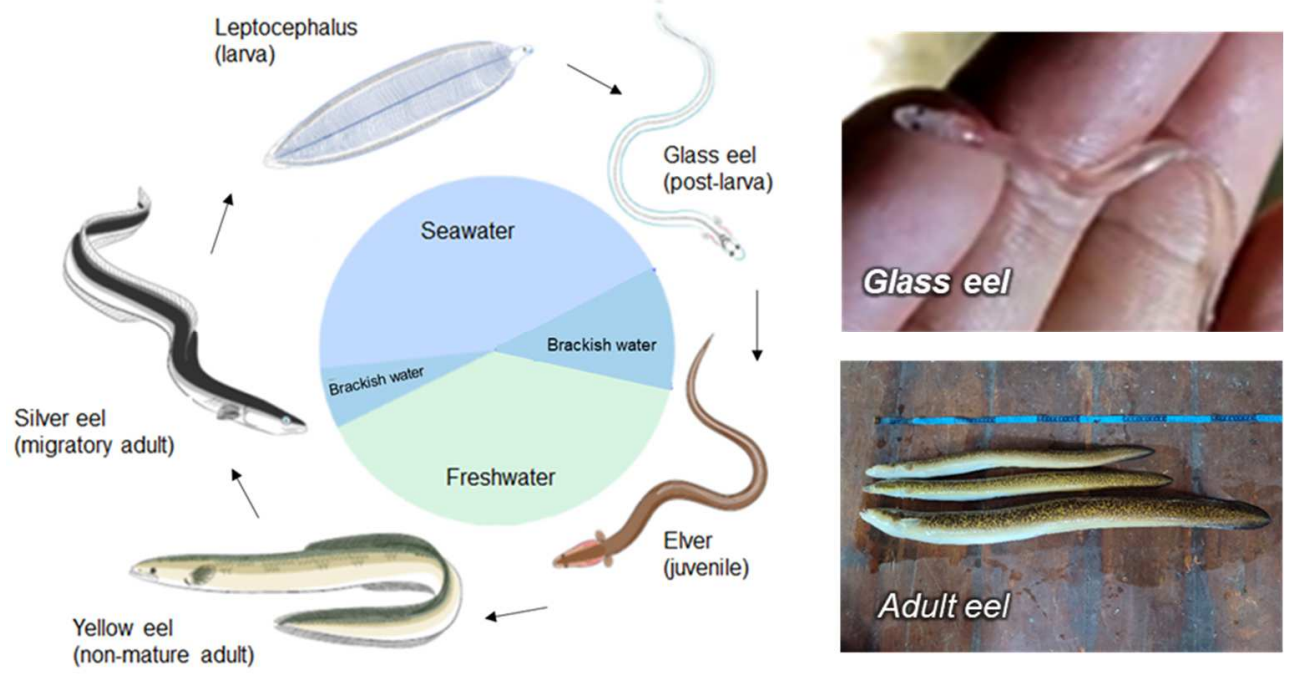

Fig. 5. The life cycle of the eel as catadromous fish [24].

As previously mentioned, the adult eels need to migrate to the sea. Therefore the path for migration is essential, and should be no obstacles along the migration path. Adult eels caught by waya masapi are adult eels that will migrate to spawn. The migration process of adult eels to spawn occurs throughout the year. The peak of migration occurs in January to mid-August (from the rainy season to the beginning of the dry season) [4]. The process of gonad maturation in adult eels occurs when they migrate to the sea [25]. Glass eel is a juvenile of eel that migrates through river estuary to grow and develop in freshwaters such as rivers, swamps, and lakes. As a migrating fish, the obstacles that occur due to the capture or failure of the eel to reach the ocean for downstream migration and reach fresh water in upstream migration can break the eel's life cycle. 


\subsection{Establishment of conservation areas and regulation on eel fishing}

Conservation of fish resources is an essential part of fisheries resources (fisheries sustainability) and the community's economy (economic sustainability). An effort to protect these resources is by providing suitable locations to support the eel's life. The survival of the eel as a migratory fish is determined by the presence of a portion of the adult eel population that successfully migrated to reproduce and a portion of the glass eel or elver population to grow into adult eels. According to research [26], the sustainability of eel fishery production is highly dependent on the availability of glass eels from nature and the success of adult eels migrating to the sea to spawn. Poso Regency has established another protected area by stipulating it as a corridor area for protected species or marine biota. Poso Regency Regional Regulation No: 8 the year 2012 concerning Spatial Planning of Poso Regency for 2012-2032 stipulates that the Tomasa River area is designated for eel conservation area [27].

Nationally, the capture of eels is regulated through several regulations. The restriction on the size of eels that can be exported is $150 \mathrm{~g} / \mathrm{Ind}$. [28]. This restriction is intended for glass eel size of $0.13-0.20 \mathrm{~g} / \mathrm{Ind}$. Cultured to a specific size to provide added value to fishers before being exported. This regulation can encourage the use of eel seeds for cultivation purposes at local and national levels. Regarding the regulation of catching adult eels in 2020 [29], a ban has been issued to catch A. bicolor, A. interioris at sizes above $2 \mathrm{~kg}$, and A. marmorata and $A$. celebesensis above $5 \mathrm{~kg}$ all times. The regulation also imposes a ban on catching glass eels at $27^{\text {th }}-28^{\text {th }}$ in the new moon phase. The regulations are intended to maintain the sustainability of eel resources. The regulation needs to be socialized in the Poso Regency community because, based on brief interviews with fishers in the Tentena and the Poso River estuary, they are not aware of the existence of this regulation.

\subsection{Increasing the eel population through restocking program}

The eel population in the wild can increase through restocking programs. In Europe [9], restocking is considered an effort to manage and restore eel populations. Other efforts are by increasing natural recruitment and habitat improvement or restoration. Restocking eels in Poso waters has been recommended as the result of several studies. Restocking eels can be done at sizes more than $15 \mathrm{~cm}$. Eel seeds are obtained from glass eels caught in the Poso River estuary and raised first [12]. Maritime authorities and research institutes in Sweden reported that restocking and natural recruitment of eels could maintain $90 \%$ of the adult eel population (silver eel) [30].

Eel restocking must be done regularly so that the impact of its success can be felt. The essential things in restocking eels are the size of the eel stock, stocking location, and stocking time. The initial stages in the restocking process can be started from glass eel enlargement to elver. The results culture of the glass eel is then adapted to the lake. The adaptation process in the lake can be done using a pen culture system or a floating net cage system. The length of the elver adaptation process in the lake is adjusted to the size of the stocking target. The mechanism of the eel restocking program in Lake Poso can be seen in Fig. 6. 


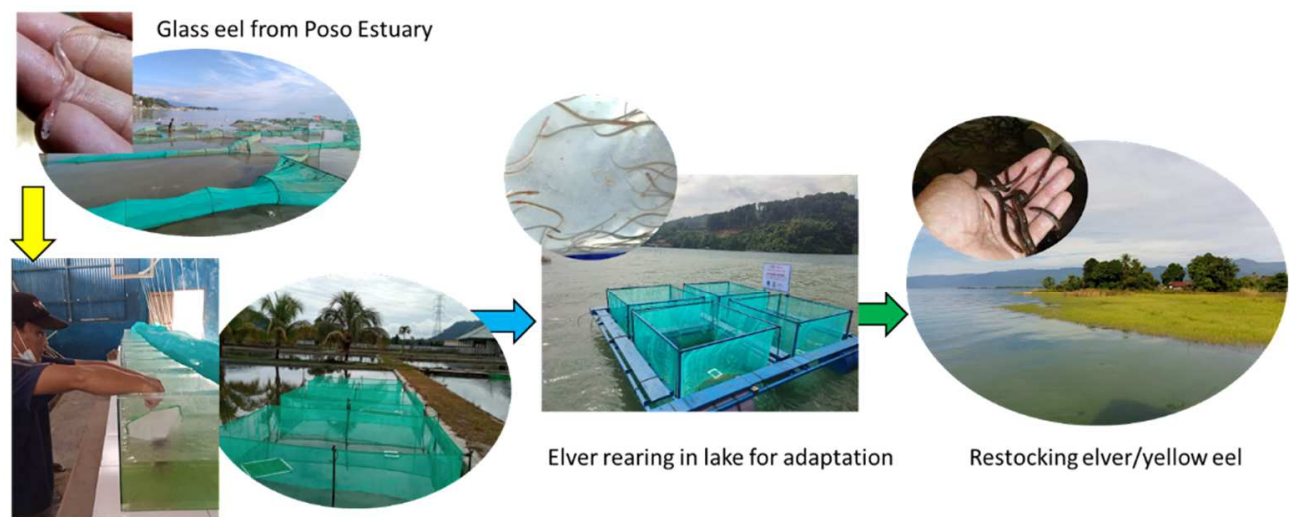

Glass eel rearing to elver in aquaculture system

Fig. 6. The mechanism of the eel restocking program in Lake Poso.

\subsection{Integration fishing activities and aquaculture}

Capture fisheries and aquaculture can be integrated to provide value for business actors (fishermen). The number of fish capture households in Poso Regency in 2018 was 509 households. The number of aquaculture households was 1091 households [31]. Fishers who catch glass eels can combine their activities into aquaculture. Catching glass eels in estuaries generally lasts a short 5-7 days per month. Glass eel storage time before being sold to collectors or cultivators is also limited to 2-3 days. Many glass eel catches cannot be sold in certain conditions where there is less demand for eel seeds. The glass eel eventually died and was sold at a low price. In such conditions, some glass eels can be raised by fishermen to a particular stage so that their utilization can be more optimal. The integration of capture fisheries activities into aquaculture can be a solution in utilizing the captured glass eel to be maintained at a particular stage to be ready for further cultivation.

The Department of Maritime Affairs and Fisheries of Poso Regency already has an eel village development program. In this program, the cultivation for eel enlargement is started in designated villages. This program includes glass eel fishers to provide the need for eel seeds for cultivation on time. If there is a failure in the cultivation process, the activity can be carried out again because the fisher can still provide glass eels as seeds for cultivation. The estimation of eel production from aquaculture can reach up to 1,000 tons/year if it raises $20 \%$ of the glass eels that enter Poso waters [7]. Eel conservation, eel cultivators who utilize glass eel from the Poso River estuary must release some of their cultivated into Poso waters. Meanwhile, adult eel fishers must buy glass eels to be released into nature. As recommended by research [7], if a fisher catches $5 \mathrm{~kg}$ of adult eel, he must buy and then release $1 \mathrm{~kg}$ of glass eel into the lake or river.

\subsection{Developing eel culture technology through the segmentation production}

The eel cultivation in the world began to be carried out around the beginning of the 20th century, namely in Japan, China, Korea, and Italy [32]. In Indonesia, eel cultivation activities began in the early 1990s. Currently, eel cultivation has emerged in several aquaculture companies in Sukabumi, Karawang, Bogor, Bandung, Jogjakarta, Cirebon, and Banyuwangi. The need for glass eel tends to increase along with the development of eel cultivation technology in the community and is related to the high demand for eel commodities globally. 
Cultivation of eels in the small and medium-scaled business community is still constrained by the high price of glass eels, the length of culture, availability of the feed, and maintenance of the facilities. These obstacles can be overcome if the production segmentation is created to have a mutually supportive cultivation chain. In fish culture, there are two business segments, namely the hatchery and the enlargement. This segmentation model is commonly found in gourami (Osphroenomus gouramy), tilapia (Oreochromis niloticus), and carp (Cyprinus carpio). In eel culture, aquaculture segmentation can be done in enlargement segmentation. The segmentation can be separated into a) from glass eel (0.13$0.2 \mathrm{~g})$ to elver $1(1-3 \mathrm{~g}), \mathrm{b})$ elver 1 to elver $2(3-5 \mathrm{~g})$, c) elver 2 to fingerling (10-20 g), and d) fingerling to consumption size $(200-300 \mathrm{~g})$. The production time from glass eel to consumption size can reach 1-1.5 years. This eel culture segmentation creates market opportunities for business actors in a not too long time. The crucial period in the segmentation of eel production is in the first segmentation, namely from glass eel to elver. In this period, good facilities and expertise are needed in rearing glass eels to elvers.

\subsection{Developing an eel migration monitoring system}

The success of eel migration is significant in determining its survival. The migration is divided into the downstream migration of adult eels and the upstream migration of larvae and young eels. Monitoring of migration process is essential to ensure the sustainability of its population in nature. The information on eel migration is obtained from the fish catch recorded by an institution or data collected by researchers $[4,7,19,20]$. However, the actual number of eels that migrate cannot be known with certainty. During the upstream migration process in the estuary, the number of glass eels can still be calculated manually from the recruitment rate.

Data on eel migration in 2001 showed that the number of migrated adult eels from Lake Poso to the sea ranged from $0-323$ eels/month or an average of 138 eels/month [4]. The number of migrated glass eels entering the Poso River during new moons ranged from 187,200-769,920 glass eels/night [19]. Compared to the study in 2011-2012, the number of glass eels migrating from the Poso river estuary reached 35,000,000 ind./year, while the adult eel migrating to the sea was 1000 eels/year [7]. However, these eel migration numbers come from estimation and calculations using various approaches; hence, the eel migration information results may have many interpretations.

The development of an eel migration monitoring system is a way to determine the number of migrating eels. The monitoring system can be developed by utilizing hydroacoustic technology. The hydroacoustic method is widely used to estimate stock abundance, geographic map distribution, and ecological information [33]. However, this technology has never yet been used to estimate the abundance of eels in nature. This method can be an alternative to estimate the abundance of eels during migration and monitor their behavior. According to [34], acoustic surveys using quantitative echo sounders have been commonly used to estimate fish abundance and biomass to provide data and information for fisheries resource management. Hydroacoustic technology can be carried out in the lake or river waters, which are usually turbid, so video or visual observations are minimal. This method can be tried in monitoring eel migration and becomes a challenge in future eel migration research.

\subsection{Building cross-sectoral forums and making joint action programs}

Collaborative management between different sectors is now an approach in managing the environment and biota resources. This collaboration involves several components: the 
government, community, business actors, universities, and research institutes. In the management of Lake Poso, guidelines have been prepared for the action program to save Lake Poso, namely "Germadan Danau Poso" [3]. In this Germadan, programs such as (1) application of science and technology, (2) institutional development, and (3) increasing community participation in lake management and conservation are planned.

At present, the management of the environment and its resources is still carried out on a sector and regional basis. Therefore, management activities often are based on the interests of each sector. Management on eel fishery should include the migration processes from upstream to downstream and vise versa involving the government, private sector, research institutions, educational institutions, and the community. As for Poso eel resources management, the actors that should be involved are the Government (Marine and Fisheries Service, the Environment Service); Private Sector (PT. Poso Energy); Research Institutes: (LIPI, BRSKP; Educational Institutions: Local universities); Community (N.G.O.s: Institut Mosintuwu, WWF Indonesia) and Indigenous institutions. In implementing activities, it is necessary to make an integrated action plan that involves all parties. The research program of "LPDP Rispro Invitasi" 2020-2021, conducted by the Research Center for LimnologyLIPI, tries to involve all components in Poso Regency to collaborate in the sustainable management of eels. The joint programs carried out include:

1) Data collection of migrating eels from Poso Lake and Poso River estuary.

2) Monitoring of eel migration on the fishway in the Poso hydropower plant area.

3) Development of eel culture through production segmentation that can be applied to the community.

4) Restocking program to increase eel population and production

\subsection{Proposing the Poso eel research and conservation center}

The Lake Poso ecosystem has unique characteristics. Lake Poso is one of two lakes in Indonesia known as ancient lakes [2]. Various types of biota were found living in this lake, namely fish, bivalves, gastropods, crustaceans, plankton, reptiles and birds, and higher plants. Ten endemic fish species live in Lake Poso and five species of eel [4]. Eels are of economic value, and as catadromous fish, eels have unique ecological properties and attracted many national and world researchers in conducting research. As a fishery commodity, the eel has a high nutritional content, so that the need for eel as food is essential. The sustainability of eel production is the hope of many people in Poso and perhaps in the world.

Poso Regency is a regency with the authority to manage Lake Poso and the biota that live in it. Poso Regency has received recognition for intellectual property as the area of origin of the $A$. marmorata eel from the Ministry of Law and Human Rights by granting a geographical indication certificate in 2019. The Poso Regency Government has determined eels to be one of the leading commodities stated in the Regional Medium-Term Development Plan (RPJMD) 2016-2021. The Poso River estuary is the largest glass eel-producing area in Indonesia. The glass eel from this estuary has been the source for eel culture not only in the area but also outside Poso Regency.

Decreases in eel catch in Poso have been reported in several studies [7,12]. Intensive fishing activities on adult eels and glass eels, barriers to migration pathways, and the influence of other environmental pressures are thought to cause the decline in the Poso eel population. Several points above encourage the existence of special units in conducting research and conservation of Poso eel. This institution can become a center for research studies collaborating with other research institutions nationally or within the region. Examples of research institutions conducting detailed research on fish resources already exist with establishing the Tuna Fisheries Research Center (LRPT) based on the regulation of the 
Minister of Marine Affairs and Fisheries of the Republic of Indonesia Number 16/PERMEN$\mathrm{KP} / 2017$. LRPT has the task of carrying out research activities on tuna fisheries resources. The research conducted covers aspects of biology, environment, population dynamics, and exploitation. LRPT also conducts research collaborations with other agencies. It is also hoped that a similar institution can be established in Poso.

\section{Conclusions}

The sustainability of the Poso eel is determined by the success of the eel migration process. The migration of adult eels to the sea and young eels to freshwater habitats must continue. The planning perspectives that can be proposed in conserving the Poso eel resources are 1) Promoting an understanding of the biological and ecological characteristics of eels as catadromous fish; 2) Determining the existence of conservation areas and regulation on eel fishing; 3) Recovering and increasing eel population through restocking 4) Synergizing fisheries and aquaculture activities to provide added value to the community; 5) Developing eel cultivation technology through size segmentation system; 6) Developing eel migration monitoring system; 7) Establishing a cross-sector communication forum and create a joint action program in the eel resources management; 8) Establishing a Poso eel research and conservation institute.

\section{Acknowledgements}

The author would like to thank the LPDP RISPRO Invitasi Project Research through the Ministry of Finance Republic of Indonesia, which contributed to funding this research activity 2020. The author also thanks the local government of Poso Regency, all collaborators, and parties that involved and participated in the research.

\section{References}

1. Lukman, I. Ridwansyah. LIMNOTEK XVI. 2, 64-73 (2009)

2. Lenny S.S, O.D.S. Hasan, M.F. Rahardjo, Danau Poso, danau purba jantungnya Wallace (MII, Cibinong, 2020)

3. Ministry of the Environment of Indonesia Republic, Poso Lake rescue movement (Ministry of the Environment, Jakarta, 2014)

4. H.Y. Sugeha, J. Aoyama, K. Tsukamoto, LIMNOTEK. 1, 18-25 (2006)

5. F.W. Tesch, The eel biology and management of Anguillid eels (John Wiley and Sons, New York, 1977)

6. F.W. Tesch, The eel third edition (Blackwell Science, Oxford, 2003)

7. N.N.J. Watupongoh, J. Krismono, Kebijak. Perikan. Ind. 7, 1 (2015)

8. I.I. Mahi, M.S. Baskoro, S.H. Wisudo, T.W. Nurani, B. Wiryawan, Int. J. Sci. : Basic Appl. 38, 1 (2018)

9. E. Feunteun, Ecol. Eng. 18, 575-591 (2002)

10. M.C. Tseng, W.N. Tzeng, S.C. Lee, Zool. Stud. 42, 2 (2003)

11. E. Tanaka, Fish. Sci. 80, 1129-1144 (2014)

12. Krismono, E.S. Kartamihardja, J. Kebijak. Perikan. Ind. 4, 1 (2012)

13. Decree of Ministry of Environmental No. 28, (Ministry of Environmental of Indonesia, Jakarta, 2009) (in Bahasa Indonesia) 
14. M.G. Ishak, Media Litbang Sulteng. 1, 1-5 (2010)

15. PT. Poso Energy, Poso peaker HEPP (515 MW) company profile (PT. Poso Energy, Poso, 2020)

16. K.T. Dewi, M. Hanafi, J. Mar. Sci. Technol. 5, 1 (2013)

17. T. Muryanto, D. Sumarno, Buletin Teknik Litkayasa 14, 2 (2016)

18. I.I. Mahi, Ph.D, Thesis, Bogor (ID) : IPB University, (2019)

19. Haryuni, Postgraduate Thesis, Bogor (ID) : IPB University, (2002)

20. H.Y. Sugeha, J. Fish. Sci. 7, 2 (2010)

21. V.J.Tv. Ginneken, G.E. Maes, Rev. Fish Biol. Fisheries 15, 367-398 (2006)

22. P.M. Lokman, M.J. Wylie, M. Downws, A.D. Biase, E.L. Damsteegt, Aquac. 437: 111119 (2014)

23. K. Tsukamoto, T. Arai, Mar. Ecol. Prog. Ser. 220, 265 -276 (2001)

24. A. Cresci, C.M. Durif, C.B. Paris, S.D. Shema, A.B. Skiftesvik, H.I. Browman, Commun. Biol. 2, 366 (2019)

25. S.H. Gadis, Lukman, Triyanto, J. Iktiologi Indones. 8, 1 (2008)

26. Triyanto, R. Affandi, M.M. Kamal, G.S. Haryani. Risalah Kebijakan Pertanian dan Lingkungan 6, 2 (2019)

27. Governmental regulation of Poso Regency, Spatial plan for Poso Regency for 2012-2032 (Pemkab Poso, Poso, 2012) (in Bahasa Indonesia)

28. Decree of Ministry of Marine Affairs and Fisheries No. 19, (MMAF, Jakarta, 2012) (in Bahasa Indonesia)

29. Decree of Ministry of Marine Affairs and Fisheries No. 80, (MMFAF, Jakarta 2020)

30. L. Fekri, T. Budiardi, R. Affandi, Eel seed restocking technique in pulic waters (IPB Press, Bogor, 2019) (in Bahasa Indonesia)

31. The Central Bureau of Statistics of Poso, Poso regency in figures 2019 (BPS Kab Poso, Poso, 2019) (in Bahasa Indonesia)

32. I. Matsui, Theory, and practice of eel culture (Tokyo-JP, 1984)

33. M. Kang, M. Furusawa, K. Miyashita, ICES J. Mar. Sci. 59, 794-804 (2002)

34. E.J. Simmonds, D.N. MacLennan, Fisheries acoustic: theory and practice (Blackwell Science Ltd., London, 2005) 